\title{
Corporate Governance Characteristics and Earnings Management: Empirical Evidence from Chinese Listed Firms
}

\author{
M. Awais Gulzar (corresponding author) \\ School of Management, Huazhong University of Science and Technology, \\ Wuhan, P.R. China 430074. \\ Tel: 86-1343-7166338_Ｅ-mail: awaisopf@hotmail.com \\ Zongjun Wang \\ School of Management, Huazhong University of Science and Technology, \\ Wuhan, P.R. China 430074 \\ E-mail: wangz_66@163.com
}

Received: August 12, 2011 Accepted: September 09, $2011 \quad$ DOI: 10.5296/ijafr.v1i1.854

\begin{abstract}
The purpose of this paper is to investigate the efficiency of corporate governance characteristics in reducing earnings management among the listed firms of Shanghai and Shenzhen stock exchange, China. We took abnormal working capital accruals as a proxy for earning management. In this paper, we used modified Jones Model in order to calculate discretionary accruals (DAC). The sample comprises of 1009 firms over the period of 4 years from 2002 to 2006. The study essentially shows that the corporate governance characteristics play a vital role in reducing the earning management. We found a significantly positive association between earning management and different corporate governance characteristics such as CEO duality, board meetings, females directors and concentrated ownership. We lacked evidences to find relationship between board size, director's shareholdings and proportion of independent directors with DAC as well as between the presence of audit committee and DAC. These studies will broaden the scope of the relationship between earning management and corporate governance characteristics. Very few studies have been conducted in this area especially for the Chinese listed firms with empirical evidences given. A variety of corporate governance variables are used especially board sex ratio in this analysis.
\end{abstract}


Keywords: Corporate governance, Earnings management, Board of directors, Discretionary accruals, Ownership, China

\section{Introduction}

After several recent financial scandals, such as Worldcom, Enron or Xerox, there has been an international movement towards developing and implementing corporate governance mechanisms to fight against the opportunistic behaviors that have undermined investors' reliability in financial information (1). Separation between ownership and control, will lead managers to manipulate earnings in order to maximize their own interest thus influencing the informativeness of earnings. The kind nature of earning management provides the opportunity to managers to manipulate the financial information of firms in order to get their own benefit. Thus in order to protect the rights of the stakeholders, it is vital for an organization to have an effective corporate governance mechanism which can control the asymmetry of financial information. In recent years, the extensive consideration given to corporate governance issues suggests that stronger governance mechanisms would reduce opportunistic management behavior, thus improving the quality and reliability of earning management.

From the last three decades, China has experienced an outstanding period of rapid growth. It grew at an average rate of about $9.7 \%$ per year during this period, with a strong growth averaging about $11 \%$ per year between 2003-2007. Growth remained strong during the recent global financial crisis, reflecting massive stimulus and strong underlying growth drivers.

China became the world's second largest economy in 2010 with a total GDP of US\$ 4.98 trillion; increasingly, it is playing an important and influential role in the global economy. These developments attract increased attention from international investors to China's equities to utilize the world's largest labor pool, as well as to penetrate the biggest and fastest growing market in the developing world.

Despite the fact that earnings management is a widespread practice among China's listed firms, little empirical work has been done to study the occurrence and the magnitude of earnings management in China. Chinese listed firms have strong incentives to do earnings management, especially to meet regulation requirements to raise new equity capital in the stock market.

The earlier studies provide strong evidence that Chinese listed companies manipulate their earnings dramatically in order to issue new shares or to avoid being delisted. The implicit assumption is that meeting the regulatory requirements is the companies' incentive to manage their earnings. The current transitional nature of the Chinese economy provides a valuable opportunity for examining the behavior of companies with different ownership types, i.e. with state block holders or private block holders or etc (Ding. et al. 2007). The majorities of current listed Chinese companies originates from restructured SOEs and are still controlled by the State and/or other non-listed SOEs. Selecting a sample consisting of all Chinese listed companies for the purpose of providing literature, we are able to examine whether and how corporate governance mechanism affect firms' earnings management practices. 
Most of the earliest studies carried out about Chinese listed companies have so far focused on just one particular characteristic of corporate governance. Some researchers only observed the effect of independent directors (Lai and Tam. 2007). Ding et al. 2007 mainly studied the impact of private vs. state ownership. This paper differs from earlier studies in a following way. It is a comprehensive study that investigates not only ownership structure but also the other aspects of China's corporate governance system.

In this paper, we examine the relation between earnings management and corporate governance characteristics specially board size, audit committee, concentration of ownership and composition of a firm's board of directors. We are particularly interested in the role played by corporate governance characteristics and their background in corporations. The major focus of the study is to get an understanding that the presence of corporate governance mechanism is effective in controlling the earnings management nature in the Chinese listed companies.

Previous studies have examined some characteristics of corporate governance in mitigating earning management. But this is a unique study using a variety of corporate governance characteristics together in order to check their combine effect in mitigating the earning management.

In the next section, we discuss the literature regarding earning management and corporate governance characteristics and develop a set of research hypotheses. In Section III we describe our sample and empirical methods, including the way we measure discretionary accruals and explanatory variables. Section IV presents our empirical results. Finally, in Section V, we give some concluding remarks.

\section{Corporate Governance and Earning Management}

Earnings management can be defined as the adjustment of a firms' reported economic performance by insiders either to mislead some stakeholders or to influence contractual outcomes. Earnings management is more informative and trustworthy if they are followed by a good governing system.

Earnings management, unlike fraud, involves the selection of accounting procedures and estimates that conform to generally accepted accounting principles (GAAP). That is, any firms that have earnings management would be manifested within the bounds of accepted accounting procedure manipulation. (Rahman and Ali 2007)

The act of managing earnings does not necessarily reflect the true performance of the company, a situation that may contribute to shareholders and investors making inaccurate judgments about the company. Thus, effective board monitoring is important in reducing the incidence of earnings management when incentives for such manipulations are high.

It defines corporate governance as the system by which business corporations are directed and controlled (Kajola, Sunday O, 2008). The corporate governance structure specifies the distribution of rights and responsibilities among different participants in the corporation such 
as, the board, managers, shareholders and other stakeholders, and spells out the rules and procedures for making decisions on corporate affairs

\subsection{Board Composition}

The size to which increased levels of outside director representation on the board of directors protect the rights of shareholders is the focus of much discussion. According to agency theory, outside directors should be dominated in the board inorder to increase the board's independence from management. Several papers provide evidence supporting that there is a negative relationship between the independent outside directors and earning management.( Brickley and James, 1987; Weisbach, 1988; Byrd and Hickman, 1992; Lee et al., 1992). Others provide empirical evidences to support a negative relationship between performance of a firm and the proportion of outside independent directors (Dechow et al., 1996; Beasley, 1996; Bhagat and Black, 2000; Klein, 2002; Xie et all, 2003; Rahman and Ali, 2007).

H1. There is a significant negative relationship between discretionary accruals (DAC) and the proportion of independent directors on the board.

\subsection{Duality}

Another important characteristic of board is CEO Duality. In CEO duality, the CEO of the firm wears two hats, a chairperson of the board of directors hat and a CEO hat . Non-duality means that different individuals serve as the chairperson and the CEO. Usually it is assumed that the monitoring ability of the board is less if the CEO in a firm also acts a chairman of the board in the same firm. The companies with CEO duality did not perform as well as their competitors (Abdul Rahman and Haniffa, 2005). However, empirically, most authors do not find any significant positive relation between CEO duality and earning management. So it seems not to support this theory. (Bugshan, 2005; Cornett, Marcus, Saunders \& Tehranian, 2006; Davidson et al., 2005, Rahman and Ali 2007, Meca \& Ballesta 2009).

H2. There is a significant negative relationship between discretionary accruals (DAC) and the separation of the roles of CEO and chairman.

\subsection{Board Size}

Another important characteristic that can affect the monitoring ability of the board is board size. Empirical research has acknowledged that board size may be related to firm performance. Earlier studies demonstrate that smaller boards are associated with better firm performances. The board size of four to six members might be more effective since they are able to make effective communication and well timely strategic decisions. (Jensen (1993), Goodstein et al. (1994), Yermack (1996), Eisenberg et al. (1998)). Some authors found a positive association between board size and earnings management (Chin et al, 2006, Rahman and Ali 2007), and others find a negative relation (Peasnell et al. 2001, Xie et al, 2003) or even no relation (Bradbury et al., 2006).

H3. There is a significant positive relationship between discretionary accruals (DAC) and the 
size of boards.

\subsection{Number of Board Meetings}

Previous studies evidenced that a board meets more often should be able to monitor the board activities in order to maintain the earning management more effectively. (Xie et al, 2003, Vafeas 1999). So we can say that board meetings are inversely proportional to retained earnings. The board with lack of board meetings cannot discuss and focus on the issues of maintaining earning management.

H4. There is a significant negative relationship between discretionary accruals (DAC) and the number of board meetings.

\subsection{Board Sex Ratio}

From the last few years, the studies evidenced the emergence of an issue of board-sex diversity in corporate governance literature. Several studies have recently focused that firm's performance can be effected by the female members in the board. Carter et al. (2003), Farrell and Hersch (2005), Rose (2007), Campbell and Minguez-Vera (2008), Adams and Ferreira (2009) and Emilia \& Sami (2010) examine the effects of female executives and directors on the firm's financial performance and market value.

Fondas and Sassalos (2000) argued that the heterogeneous boards are more efficient than homogenous boards. The presence of female's director in the board is associated with improved financial performance. (Carter et al. (2003) and Campbell \& Minguez Vera (2008). They argued that, by bringing women in the board decisions, may improve decision-making of the board.

However, some studies suggest that firm performance has no significant relationship with board gender diversity. Watson (2002) found no significant differences between male- and female-controlled firms. Rose (2007) evidenced that there is no significant association between female board representation and firm performance. Another study evidenced the negative effect of females in the board, on firm performance. Adams \& Ferreira (2009). Emilia \& Sami (2010) also found no relationship between earnings management and the gender of the firm's CEO. Thus we can conclude another hypothesis:

H5. There is a significant negative relationship between discretionary accruals (DAC) and the presence of female directors in the board.

\subsection{Audit Committee}

Audit committee is also another important characteristic of corporate governance which can effect the earning management. In 2002, after the China Securities Supervisory Commission issued the Standards of Corporate Governance for the listed companies in shanghai and shenzhen stock exchange in china, chinese listed companies are more interested to establish audit committee (Lin et al 2008). Most of the studies about the roles of the audit committee, responsibilities, and actual operations have been evidenced in other western countries over 
the last two decades. But there is a lack of studies about audit committee in china.

The establishment of the audit committee is to ensure continuous communication between external auditors and the board, where the committee meets regularly with the auditors to review financial statements and audit processes and also internal accounting systems and control. In terms of lifting the image of good corporate governance, the roles and responsibilities of ACs have been generally accepted by various groups of stakeholders. (Lin et al 2006). Previous studies argued that the audit committee plays a valuable role in supervising audit and financial functions as mentioned by Muhamad Sori et al. (2001). Thus the presence of audit committee can be a key factor influencing the earning management of the company. Choi et al. (2004) and Park and Shin (2003) found a significant relationship between the audit committee and earning management. In contrast, Peasnell et al. (2001) and Rahman and Ali 2007 found no significant relationship.

H6. There is a significant negative relationship between discretionary accruals (DAC) and the presence of the audit committee.

\subsection{Managerial Share Ownership As a Governance Mechanism}

Managerial share ownership also considered to be a characteristic of corporate governance. Gillan (2006) identified managerial share ownership as a characteristic of internal governance for resolving the contracting problems. As a result, good corporate governance mechanisms might help in the reduction of discretionary accruals by restricted the managerial share ownership. Therefore, reduce the level of error in accruals and increase earnings persistence.

Morck et al., 1988; McConnell and Servaes, 1990, Warfield et al., 1995 and Kim et al, 2004, found a curvelinear relationship instead of linear relationship, between managerial share ownership and financial restatement. Because of the large managerial share ownership, corporate managers restated the financial figures by not disclosing important information to other shareholders for their personal incentives (Fan and Wong.2002). Thus the size of managerial share ownership is estimated to be associated with financial restatement because managerial ownership indicates the extent to which corporate managers are being honest to other shareholders.

If the size of the managerial share ownership is small, corporate managers are expected to be honest with the other shareholders because of their continuous monitoring, thus there are less chances of financial restatements and financial information are expected to be free of errors or misstatements.

H7. There is a significant negative relationship between discretionary accruals (DAC) and the Managerial share ownership.

\subsection{Concentrated Ownership}

Agency theory states that less concentrated ownership may have incentives for the managers to manipulate the financial numbers for their personal benefit in order to get more 
earning-based bonuses and less pressure from other shareholders. Past studies have shown that concentrated or block ownership can increase the monitoring effectiveness of the board (Shleifer and Vishny, 1997). As concentrated ownership can restrict the opportunistic behavior of management so we can say discretionary accruals is predicted to be negatively associated with concentrated ownership (Warfield,Wild, \&Wild, 1995).

Concentrated ownership is the norm in China, and that is a powerful stumbling block to improved corporate governance and transparency. For state-owned entities, because the controlling shareholder and the regulator are government agencies, it is more difficult to implement effective checks and balances.

On the other hand, the concentrated ownership may be ineffective in prompting insiders to make valuable decisions in their own interest, which may result in increase discretionary accruals (Cornett, Marcus, \& Tehranian, 2008). Koh, 2003, Bowen et al, 2004, Davidson et al. (2005) and Sánchez-Ballesta and García-Meca (2007) found no significant association between concentrated ownership and earnings management.

Therefore, the presence of shareholders owning a large block of shares in a company provides an additional monitoring mechanism that may deter opportunistic earnings management:

H8. There is a significant negative relationship between discretionary accruals (DAC) and the concentrated ownership.

\section{Statistical Method}

The current study uses the cross-sectional modified version of Jones (1991) as used by Dechow et al. (1996), Peasnell et al. (2001), Klein (2002), Xie et al. (2003) and Rahman and Ali 2007. as we use the same procedure and for the sake of briefness, we only summarize it here and refer the reader to Jones (1991), Dechow et al. (1995), Peasnell et al. (2001) and Rahman and Ali 2007.

The vast majority of recent earnings management literature has used abnormal accruals (or discretionary accruals, DA) as a proxy for earnings management. Therefore, this study uses abnormal accruals to measure earnings management.

In employing the modified Jones’ (1991) model, working capital accruals are decomposed into non-discretionary and DAC. The non-DAC or normal accruals are estimates by managers that represent changes in the underlying economic performance of the company. For example, as the level of sales and purchases during the growth period increases, the magnitude of accounts payable and accounts receivable would increase accordingly. On the other hand, DAC are open to managers' discretion and hence are operationalised as a proxy for earnings management in the study.

Non-DAC are estimated during the observation year (the year in which earnings management is estimated) as: 


$$
N D A C_{i, t}=\propto\left(\frac{1}{T A_{i, t-2}}\right)+\beta\left(\Delta R E V_{i t}-\frac{\Delta R E C_{i, t}}{T A_{i, t-1}}\right)
$$

where

NDACt $=$ non-DAC for company $i$ in year $t$ scaled by lagged total assets

$\mathrm{RECi} ; \mathrm{t}=$ net receivables for company $\mathrm{i}$ in year $\mathrm{t}$ less net receivables in year $\mathrm{t}-1$;

$\mathrm{REVi} ; \mathrm{t}=$ revenues for company $\mathrm{i}$ in year t less revenues in year $\mathrm{t}-1$;

TAi;t-1 = total assets for company $\mathrm{i}$ at the end of year $\mathrm{t}-1$;

(a and b are industry-specific parameters)

In order to reduce heteroscedasticity problems, we deflate all variables in the regression model by the lagged of total assets (Teoh et al., 1998):

$$
\frac{W C A_{j, t}}{T A_{j, t-1}}=\alpha_{1}\left(\frac{1}{T A_{j, t-1}}\right)+\beta_{1}\left(\frac{\Delta R E V_{j, t}}{T A_{j, t-1}}\right)+\varepsilon_{t}
$$

where

WCAj; $\mathrm{t}$ = working capital accruals in year t for industry $\mathrm{j}$; defined as change in non-cash current assets minus the change in current liabilities, a1and b1, denote the OLS estimates of $\mathrm{a}$ and $\mathrm{b}$ in equation (1) above, $1 \mathrm{t}$; the regression residuals

We then define the discretionary current accruals, DCAit, as the remaining portion of the current accruals:

$$
D A C_{i, t}=W C\left(\frac{1}{A_{i, t}}\right)-N D A C_{i, t}
$$

\section{Data}

Our sample, obtained from the China Center for Economic Research, CCER, consists of year-end data for all the listed firms of Shanghai and Shenzhen stock exchange, China. The sample contains 1011 firms over the period of 2002 to 2006. Of these initial 1011 firm year observations, firms that are either missing financial variables or that have insufficient data in order to estimate performance-matched abnormal accruals are eliminated. Financial institutions are also eliminated, since their special accounting methods make the estimation of 
discretional accruals problematic. Companies that do not have complete financial data, complete information on directors or whose annual reports are unavailable are also excluded.

Table I. Definition of Variables

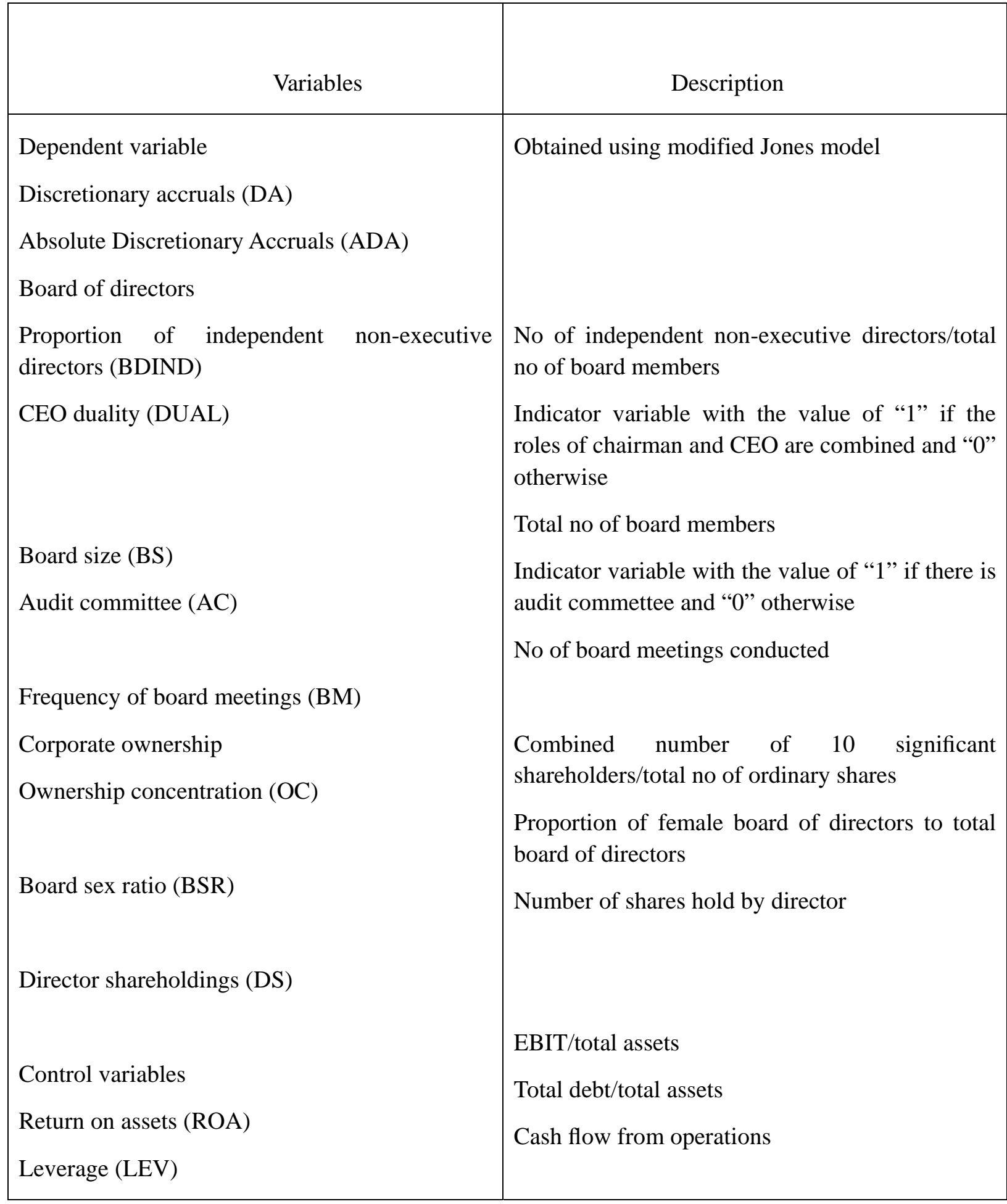




\subsection{Measurement}

We use absolute value of discretionary current accruals DAC as the dependent variable as consistent with Klein (2002) and Xie et al (2003). Table 1 provides the variables and their specific definition in the study. The descriptive statistics of the DAC and the continuous independent variables used in the sample are shown in Tables II.

Following are the variables that symbolize the characteristics of board of directors i.e. CEO duality, proportion of independent directors, board size, No of board meetings conducted and Board sex ratio. We classify the term "CEO duality" as the separation of the role of chairman and CEO. When the same person occupies both CEO and chairman of board position, we labeled that firm with the value " 1 " and as 0 otherwise. We also take the number of board meetings as a characteristic of board. In our sample firms, the mean value of board meetings is 7.89, but the range is from 2 to 34. Board size describes the total number of board members, similar to that used by Xie et al. (2003) and Peasnell et al. (2001). The mean value for board size is 6.687, however the maximum is 19 . The proportion of independent directors on the board is measured by dividing the total number of independent non-executive directors by the total number of board members (Klein, 2002; Xie et al., 2003; Peasnell et al., 2001). Board sex ratio is the number of female directors divided by number of total board of directors. The mean value for board sex ratio is 0.866 , however the maximum is 1 .

We categorize Audit Committee variable as a dummy variable. If there is an audit committee in a firm, we labeled that firm with the value 1 and as 0 otherwise.

Similar to the studies conducted by Chtourou et al. (2001) and Abdul Rahman and Haniffa (2003), concentrated ownership is based on the percentage shareholding of the ombined number of significant shareholders in a company.

We also use four control variables in our study that prior studies have found to be associated with earnings management or governance variables. These variables other then governance variables, may also helpful in reducing earning management. Following are the four control variables used in this study. Return on assets (ROA), Leverage (LEV), Cash flow (CF) and Size (SIZE).

If the firm has higher leverage and its performance is low, then there are more chances of earnings manipulation. Because the firm has higher bankruptcy risk, which in turn will lead to litigation risks.

Leverage (LEV) measured as the ratio of total liabilities to total assets, captures the incentives to practice earnings management when close to debt covenant violations (Klein, 2002).

The absolute change in earnings has been found to be positively associated with earnings management (Klein, 2002) and we measure this by the absolute change in net income 
between the current and prior periods scaled by total assets .

We include the log of total assets (SIZE) to control for the effect of size as this has been found to be negatively associated with earnings management and positively associated with audit committee and board independence and the use of internal audit (Klein, 2002). In addition, the log of book value of total assets is used as a proxy for size because smaller firms are less scrutinized by authorities and is therefore more inclined to manage earnings (Xie et al., 2003).

Becker et al. (1998) and Dechow et al. (1995) reported a significant negative association between DAC and cash flow. This particularly so in the event where companies are close to debt covenant restrictions, quite is often the level of cash flow is also low. Hence, managers are more inclined to manage earnings with upward trend.

Table 2. Descriptive Statistics

\begin{tabular}{lccccccc}
\hline & Mean & Minimum & Median & Maximum & Skewness & Kurtosis & SD \\
\hline ADA & 0.073 & 0.000 & 0.050 & 1.246 & 3.722 & 26.240 & 0.082 \\
BDIND & 0.484 & 0.000 & 0.500 & 2.000 & 0.582 & 5.518 & 0.154 \\
BS & 6.687 & 0.000 & 6.000 & 19.000 & 1.108 & 2.773 & 1.864 \\
BM & 7.896 & 2.000 & 7.000 & 34.000 & 1.931 & 7.167 & 3.183 \\
BSR & 0.867 & 0.350 & 0.880 & 1.000 & -0.895 & 0.939 & 0.097 \\
DS & 0.001 & 0.000 & 0.000 & 0.235 & 25.206 & 694.906 & 0.008 \\
OC & 0.594 & 0.019 & 0.608 & 0.995 & -0.400 & .381 & 0.133 \\
LEV & 0.724 & 0.008 & 0.512 & 877.256 & 70.883 & 5034.442 & 12.343 \\
SIZE & 9.227 & 5.348 & 9.203 & 11.774 & 0.222 & 2.903 & 0.435 \\
CF & 18.400683 & 9.6178 & 18.493819 & 25.354 & -0.385 & 1.86 & 1.542615 \\
ROA & 0.010 & -1.752 & 0.022 & 0.889 & -7.618 & 93.659 & 0.111
\end{tabular}


Note: Absolute Discretionary Accruals (ADA), Proportion of independent non-executive directors (BDIND), CEO duality (DUAL), Board size (BS), Audit committee (AC), Frequency of board meetings (BM), Board sex ratio (BSR), Director shareholdings (DS), Ownership concentration (OC), Leverage (LEV), Size (SIZE), Cash flow (CF), and Return on assets (ROA).

\subsection{Multivariate Regression}

Table IV shows the multivariate regression model results in order to measure the explanatory power of corporate governance variables (independent variables) against discretionary current accruals (dependent variable).

There is a significant positive relationship between CEO duality and DAC which means that by separating the role of CEO and Chairman, helps in reducing earning management. This result is consistent with the Klein (2003) who also found the significant relationship among DAC and CEO duality. Abdul Rahman and Hanifa also found that the companies with CEO duality did not perform as well as their competitors.

Table IV shows that there is a significant positive relationship between board size and DAC which means the larger the board, the more ineffective in its function. Smaller boards are associated with low level of discretionary current accruals.

The results also indicate the significant positive relationship between number of board meetings and DAC, indicating lower discretionary accruals with more often board meetings. The board will consider to be active in monitoring its activities if they are meeting more often.

We have not found any association between the level of DAC and the presence of an audit committee (AC) in a firm. Our results are consistent with Peasnell et al. (2001) and Rahman and Ali 2007 who also found no significant relationship between audit committee and DAC.

We also find a significant positive relationship between DAC and concentration of ownership which means concentration of ownership also plays a significant role in reducing discretionary current accruals by preventing the opportunistic behavior of managers. Our results are not consistent with Rahman and Ali 2007, Bowen, Rajgopal, \& Venkatachalam, 2004; Koh, 2003 who found no significant relationship between DAC and concentration of ownership.

We also find no significant relationship between DAC and proportion of independent directors. This result is consistent with the results of Chtourou et al. 2001, Choi et al. 2004 and Rahman and Ali 2007 and is in contrast with the results found by Klein (2002), Xie et al. (2003) and Peasnell et al. (2001) where independent directors are negatively related to DAC.

There is insufficient empirical evidence to accept this hypothesis where we find no significant relationship between DAC and directors shareholdings. 
Table 3. Correlation Analysis

\begin{tabular}{|c|c|c|c|c|c|c|c|c|c|c|c|}
\hline & ADA & BDIND & BS & $\mathrm{BM}$ & BS & DS & OC & LEV & SIZE & CF & ROA \\
\hline $\mathrm{ADA}$ & 1.00 & & & & & & & & & & \\
\hline BDIND & .020 & 1.00 & & & & & & & & & \\
\hline BS & $-.041 * * *$ & $k-.577 * * *$ & ${ }^{k} 1.00$ & & & & & & & & \\
\hline $\mathrm{BM}$ & $.070 * * *$ & -.013 & -.008 & 1.00 & & & & & & & \\
\hline BSR & $-.044 * * *$ & ${ }^{k}-.052 * * *$ & $\begin{array}{l}.077^{* *} \\
*\end{array}$ & $-.060 * * *$ & * 1.00 & & & & & & \\
\hline DS & -.011 & -.004 & -.010 & -.013 & .001 & 1.00 & & & & & \\
\hline OC & .005 & $-.062 * * *$ & $\begin{array}{l}.100 * * \\
*\end{array}$ & $-.042 * * *$ & ${ }^{*} .142 * * *$ & -.019 & 1.00 & & & & \\
\hline LEV & $.037 * * *$ & .012 & .023 & .006 & -.005 & -.002 & $\begin{array}{l}-.029 * \\
*\end{array}$ & 1.00 & & & \\
\hline SIZE & $-.084 * * *$ & ${ }^{*} .049 * * *$ & $\begin{array}{l}.163^{* *} \\
*\end{array}$ & .008 & $.163^{* * *}$ & -.013 & $\begin{array}{l}.103^{* *} \\
*\end{array}$ & $\begin{array}{l}-.134 * \\
* *\end{array}$ & 1.00 & & \\
\hline CF & .018 & -.001 & $\begin{array}{l}.058 * * \\
*\end{array}$ & .004 & $.064 * * *$ & -.005 & $\begin{array}{l}.122 * * \\
*\end{array}$ & -.002 & $\begin{array}{l}.302 * * \\
*\end{array}$ & 1.00 & \\
\hline ROA & $-.268 * * *$ & k -.002 & $\begin{array}{l}.051 * * \\
*\end{array}$ & $-.058 * * *$ & *.046*** & $.024^{*}$ & $\begin{array}{l}.123 * * \\
*\end{array}$ & $\begin{array}{l}=-156 * \\
* *\end{array}$ & $\begin{array}{l}.278 * * \\
*\end{array}$ & $\begin{array}{l}.057 * * \\
*\end{array}$ & 1.00 \\
\hline
\end{tabular}

$* * *, * *$ and $*$ represents correlation is significant at $0.01,0.05$ and 0.10 level (2-tailed) respectively.

Note: Absolute Discretionary Accruals (ADA), Proportion of independent non-executive directors (BDIND), Board size (BS), Frequency of board meetings (BM), Board sex ratio 
(BSR), Director shareholdings (DS), Ownership concentration (OC), Leverage (LEV), Size (SIZE), Cash flow (CF), and Return on assets (ROA).

Table 4. Multiple Regression

\begin{tabular}{|c|c|c|}
\hline & Coefficients & $\mathrm{t}$ \\
\hline Constant & $0.102 * * *$ & 3.642 \\
\hline BDIND & 0.008 & 0.497 \\
\hline DUAL & $0.040 * * *$ & 2.914 \\
\hline BS & -0.023 & -1.360 \\
\hline BM & $0.056 * * *$ & 4.092 \\
\hline BSR & $-0.030 * *$ & -2.159 \\
\hline $\mathrm{AC}$ & 0.006 & 0.406 \\
\hline DS & -0.004 & -0.290 \\
\hline OC & $0.050 * * *$ & 3.618 \\
\hline LEV & -0.005 & -0.340 \\
\hline SIZE & -0.016 & -1.060 \\
\hline CF & $0.036 * * *$ & 2.507 \\
\hline ROA & $-0.267 * * *$ & -18.665 \\
\hline
\end{tabular}

Note: Absolute Discretionary Accruals (ADA), Proportion of independent non-executive directors (BDIND), CEO duality (DUAL), Board size (BS), Audit committee (AC), Frequency of board meetings (BM), Board sex ratio (BSR), Director shareholdings (DS), Ownership concentration (OC), Leverage (LEV), Size (SIZE), Cash flow (CF), and Return on assets (ROA).

We also a find a significant positive relationship between DAC and gender based difference 
in the board which means that the presence of more females directors in the board help to reduce discretionary accruals as women are less involve in manipulating the earnings and frauds.

Among control variables, the results reported only cash flow and ROA are significantly related to DAC which means that the managers are more inclined to manage earnings upwards if the value of cash flow is low. Our results are consistent with Becker et al. (1998) and Dechow et al. (1995).

\section{Conclusion}

The main purpose of this study is to observe the relationship between corporate governance characteristics and earning management. The motivation behind this study is the contrast between the theory and empirical evidence that earnings management and poor corporate governance mechanisms are positively related. We find negative associations between corporate governance characteristics and discretionary current accruals.

Most of the board of director's characteristics is significantly associated with the earnings management except board size, director's shareholdings and proportion of independent directors. We find no relationship between board size, director's shareholdings and proportion of independent directors with DAC. Our results find that by separating the role of CEO and Chairman, helps in reducing earning management. We also find that if the frequency of board meetings is more, then the value of discretionary accruals is lower. Higher frequency of board meetings will improve the board monitoring. The study shows that presence of female's directors in the board also helps to reduce the level of earning management.

Our results also find that concentrated ownership plays a significant role in reducing discretionary current accruals by preventing the opportunistic behavior of managers. We find no relationship between the presence of audit committee and DAC.

Finally we can conclude that a negative relationship exists between corporate governance characteristics and earning management among all the Chinese listed firms. So in this view, by making the governance system stronger in the firm, can protect the shareholders from earning management. This paper uses cross-sectional modified version of Jones to measure the DAC so still, future work needs to be done on finding more accurate measures of DAC so that we can focus on the relationship of corporate governance characteristics and earning management. We can also limit the data of Chinese listed firms to state owned and private firms for future study to see more accurate results. However, the results indicate that these models provide help in understanding the earning management behavior of Chinese firms.

\section{References:}

Abdul Rahman, R. and Haniffa, R. (2005). The effect of role duality on corporate performance in Malaysia. International Scientiï $\neg$ c of Corporate Ownership and Control, Vol. 2 No. 2, pp. 40-7.

Adams, R. and Ferreira, D. (2009). Women in the boardroom and their impact on governance 
and performance. Journal of Financial Economics, Vol. 94, pp. 291-309.

http://dx.doi.org/10.1016/j.jfineco.2008.10.007

April Klein. (2002). Audit committee, board of director characteristics, and earnings management. Journal of Accounting and Economics, 33 375â "400.

Beasley, M.S., (1996). An empirical analysis of the relation between the board of director composition and financial statement fraud. The Accounting Review, 71, 443â “465

Bhagat, S., Black, B., (2000). Board independence and long-term performance. University of Colorado Working Paper.

Biao Xie, Wallace N. Davidson III, Peter J. DaDalt, (2003). Earnings management and corporate governance: the role of the board and the audit committee. Journal of Corporate Finance, $9295 a ̂$ “316.

Bowen, R., Rajgopal, S., \& Venkatachalam, M. (2004). Accounting discretion, corporate governance and ï $\neg$ rm performance.Working Paper SSRN, University of Washington.

Bradbury, M., Mak, Y., \& Tan, S. (2006). Board characteristics, audit committee characteristics, and abnormal accruals. Paciï c Accounting Review, 18: 47â “68.

Brickley, J.A., James, C.M., (1987). The takeover market, corporate board composition, and ownership structure: the case of banking. Journal of Law and Economics, 30, 161â “181.

Bugshan, T. (2005). Corporate governance, earnings management and the information content of accounting earnings: Theoretical model and empirical tests. Ph.D. Dissertation, Bond University, Australia.

Byrd, J., Hickman, K., (1992). Do outside directors monitor managers? Evidence from tender offer bids. Journal of Financial Economics, 32, 195â “221.

Campbell, K. and Minguez-Vera, A. (2008). Gender diversity in the boardroom and firm financial performance. Journal of Business Ethics, Vol. 83, pp. 435-51.

http://dx.doi.org/10.1007/s10551-007-9630-y

Carter, D., Simkins, B. and Simpson, W. (2003). Corporate governance, board diversity, and firm value. The Financial Review, Vol. 38, pp. 33-53.

http://dx.doi.org/10.1111/1540-6288.00034

Chin, K., Firth, M., \& Rui, O. (2006). Earnings management, corporate governance, and the market performance of seasoned equity offerings. Journal of Contemporary Accounting and Economics, 73â "98. 
Choi, J.H., Jeon, K. A. and Park, J. I. (2004). The role of audit committees in decreasing earnings management: Korean evidence. International Journal of Accounting and Performance Evaluation, HongKong.

Chtourou, S.M., Bedard, J. and Courteau, L. (2001). Corporate governance and earnings Management. working paper, University of Laval Canada.

Cornett, M., Marcus, A., \& Tehranian, H. (2008). Corporate governance and pay-for-performance: The impact of earnings management. Journal of Financial Economics, 87: 357â “373.

Davidson, R., Goodwin-Stewart, J., \& Kent, P. (2005). Internal governance structures and earnings management. Accounting and Finance, 45: 241â “267.

Dechow, P.M., Sloan, R.G., Sweeney, A.P., (1996). Causes and consequences of earnings manipulation: an analysis of firms subject to enforcement actions by the SEC. Contemporary Accounting Research, 13,1â "36

Ding, Y., Zhang, H., \& Zhang, J. (2007). Private vs. state ownership and earnings management: Evidence from Chinese listed companies. Corporate Governance: An International Review, 15:223â “238

Eisenberg, T.S., Sundgren, S., Wells, M., (1998). Larger board size and decreasing firm value in small firms. Journal of Financial Economics, 48, 35â “ 54.

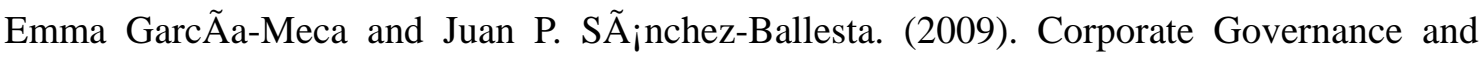
Earnings Management: A Meta-Analysis. Corporate Governance: An International Review, 17(5): 594â “610

Fan, J.P.H. and Wong, T.J. (2002). Corporate ownership and the informativeness of accounting earnings in East Asia. Journal of Accounting and Economics, Vol. 3, pp. 401-25. http://dx.doi.org/10.1016/S0165-4101(02)00047-2

Farrell, K. and Hersch, P. (2005). Additions to corporate boards: the effect of gender. Journal of Corporate Finance, Vol. 11, pp. 85-106.

http://dx.doi.org/10.1016/j.jcorpfin.2003.12.001

Fondas, N. and Sassalos, S. (2000). A different voice in the boardroom: how the presence of women directors affects board influence over management. Global Focus, Vol.12,pp.13-22.

Gillan, S. (2006). On corporate governance: An overview and introduction to the special issue. Journal of Corporate Finance, 12, 381â “402 
Goodstein, J., Gautam, K. and Boeker, W. (1994). The effect of board size and diversity on strategic change. Strategic Management Journal, Vol. 15, pp. 241-50.

http://dx.doi.org/10.1002/smj.4250150305

Jensen, M. (1993). The modern industrial revolution: Exit and failure of internal control systems. Journal of Finance, 48: 831â “880.

Kajola, Sunday O, (2008). Corporate Governance and Firm Performance: The Case of Nigerian Listed Firms. European Journal of Economics, Finance and Administrative Sciences, ISSN 1450-2887 Issue 14

Koh, P. (2003). On the association between institutional ownership and aggressive corporate earnings management in Australia. British Accounting Review, 35: 105â “128.

Kim, K., Kitsabunnarat, P., Nofsinger, J., (2004). Ownership and operating performance in an emerging market: evidence from Thai IPO ï $\neg$ rms. Journal of Corporate Finance, 10, $355 a ̂$ "381

Lai, L. and Tam, H. (2007). Independent directors and the propensity to smooth earnings: a study of corporate governance in China. The Business Review, Vol. 7 No. 1, pp. 328-335.

Lee, C.I., Rosenstein, S., Rangan, N., Davidson, W.N., (1992). Board composition and shareholder wealth. The case of management buyouts. Financial Management, 21, 58â "72

Lin et al (2006) The effect of audit committee performance on earnings management quality. Managerial Auditing journal, 21(9): 921-923

http://dx.doi.org/10.1108/02686900610705019

McConnell, J., and H. Servaes (1990). Additional evidence on equity ownership and corporate value. Journal of Financial Economics 27, 595â “612.

Morck, R., A. Schleifer, and R. Vishny (1988). Management ownership and market valuation. Journal of Financial Economics, 20, 293â “315

Muhamad Sori, Z., Mohamad, S., Abdul Hamid, M.A. and Nassir, A. (2001). The effectiveness of the audit committee: the chairmanâ ${ }^{\mathrm{TM}}$ S perception. Akauntan Nasional, February.

Park, W.Y. and Shin, H.H. (2003). Board composition and earnings management in Canada. Journal of Corporate Finance, Vol. 185, pp. 1-27.

Peasnell, K.V., Pope, P.F. and Young, S. (2001). Board monitoring and earnings management: 
do outside directors inï $\neg$,uence abnormal accruals? working paper, Lancaster University, Lancaster.

Peni, E. and Vahamaa, S. (2010). Female executives and earnings management. Managerial Finance, Vol. 36 No. 7, pp. 629-645

http://dx.doi.org/10.1108/03074351011050343

Rashidah Abdul Rahman and Fairuzana Haneem Mohamed Ali (2006). Board, audit committee, culture and earnings management: Malaysian evidence. Managerial Auditing Journal, Vol. 21 No. 7. pp. 783-804

http://dx.doi.org/10.1108/02686900610680549

Rose, C. (2007). Does female board representation influence firm performance? The Danish evidence. Corporate Governance: An International Review, Vol. 15 No. 2, pp. 404-13. http://dx.doi.org/10.1111/j.1467-8683.2007.00570.x

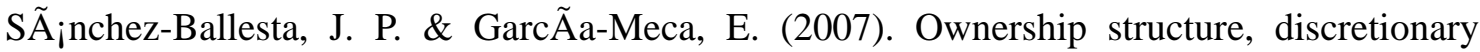
accruals and the informativeness of earnings. Corporate Governance: An International Review, 15: 677â “691.

Shleifer, A. and Vishny, R.W. (1997). A survey of corporate governance. The Journal of Finance, Vol. 52, pp. 737-83

http://dx.doi.org/10.2307/2329497

Vafeas, N., (1999). Board meeting frequency and firm performance. Journal of Financial Economics, 53, 113â “ 142 Warï eld, T.D., Wild, J.J. and Wild, K.L. (1995). Managerial ownership, accounting choices and informativeness of earnings. Journal of Accounting and Economics, Vol. 20, pp. 61-91.

Watson, J. (2002). Comparing the performance of male- and female-controlled businesses: relating outputs to inputs. Entrepreneurship Theory and Practice, Vol. 26 No. 3, pp. 91-100.

Weisbach, M.S., (1988). Outside director and CEO turnover. Journal of Financial Economics, 20, 431â “460.

Yermack, D., (1996). Higher market valuation of companies with a small board of directors. Journal of Financial Economics, 40, 185â “ 211.

Z. Jun Lin, Jason Z. Xiao. and Qingliang Tang (2008). The roles, responsibilities and characteristics of audit committee in China. Accounting, Auditing \& Accountability Journal,Vol. 21 No. 5, pp. 721-751

http://dx.doi.org/10.1108/09513570810872987 